https://doi.org/10.22364/hssl.29.1.01

\title{
“NO SENSATIONAL DISCLOSURES": FOREIGN STATES AND THE ESTABLISHMENT OF AN AUTHORITARIAN REGIME IN ESTONIA IN 1934
}

\author{
Peeter Kenkmann ${ }^{1}$ \\ Institute of History and Archaeology, University of Tartu (Estonia)
}

\begin{abstract}
On 12 March 1934, the Estonian government carried out a coup d'état and justified it by the danger allegedly posed by the radical right movement, the Estonian War of Independence Veterans' League. This article examines the reports of diplomats residing in Estonia from six countries and concludes that the foreign diplomats were convinced that the real reason for the coup was the government's fear of losing power to the Veterans as a result of the forthcoming elections. Nevertheless, the coup and the subsequent establishment of an undemocratic regime did not damage Estonia's international position.
\end{abstract}

Keywords: Estonia; coup d'état; foreign relations; loss of democracy; radical right; 1930 s

\section{Introduction}

On March 12, 1934, a coup d'état was carried out in Estonia, led by Prime Minister Konstantin Päts, and with the support of the police and the military. In the process, a new political organisation that was aspiring to power - the Estonian War of Independence Veterans' League $^{2}$ - was disbanded, using the justification of ensuring public security, and an authoritarian regime was established. There was no resistance to the coup,

1 Contact Peeter Kenkmann; peeterkenkmann@gmail.com; Institute of History and Archaeology, University of Tartu, Ülikooli 18, 50090 Tartu, Estonia.

2 The Estonian War of Independence Veterans' Central League (Eesti Vabadussõjalaste Keskliit) was established in 1929, as the result of the merger of the regional organizations that stood for the social and economic interests of soldiers who had taken part in the War of Independence, 1918-1920. At the beginning of the 1930s, the movement also started to make general political demands, and persons who had not participated in the War of Independence were also able to join. The Central League was shut down by the authorities on 11 August 1933, accused of endangering public security. On 28 October 1933, the Estonian War of Independence Veterans' League (Eesti Vabadussõjalaste Liit) was established as the successor of the Central League. 
and the majority of the Estonian political elite, state officials and the media, approved of the event. ${ }^{3}$

The coup in Estonia was part of the larger process of the collapse of democracies in Europe in the interwar period. But Dirk Berg-Schlosser noted in summarising the analysis by an international research team that there is no theory providing a universal explanation for why, in some European states, democracy survived during the interwar period, but in others, it did not. ${ }^{4}$ His co-authors John D. Stephens and Gerhard Kümmel remarked that, whereas it is generally the repression of left-wing movements that is the aim of such seizures of power, then in Estonia, exceptionally, it was carried out to remove right-radicals from the political system. ${ }^{5}$ Juan J. Linz also termed the coups that occurred in Estonia and soon after in Latvia (on 15 May 1934) as unique - it was not right or left extremists or the army that destroyed democracy, but the democratically elected leaders of these countries. According to Linz, the alternative to a coup, and the resulting establishment of an authoritarian regime, would have been an undemocratic system in Estonia, where a fascist movement would play an important role. ${ }^{6}$ Similar opinion was shared by Giovanni Capoccia, as well. ${ }^{7}$

Those few foreign scholars who do mention in their research the 1934 coup in Estonia are generally not specific in describing the danger that the Veterans posed to the Estonian political system, nor do they provide reasons for calling them extreme right-wingers or fascists. Estonian researchers who have studied the League are convinced, however, that there was not much that they had in common with the Italian fascists or the German national socialists. ${ }^{8}$ Cas Mudde proffered the term "populist radical right" to describe the ideology that is common to movements like the Veterans - it is characterised by nativism, authoritarianism and populism, but also acceptance of democracy. Fascist and national socialist movements do not fit under this definition since they are more extreme. ${ }^{9}$

The general and insufficiently substantiated views of the foreign scholars, mainly political scientists, who have studied the Veterans' organisation and the reasons for the 1934 coup, can be explained by

3 See, e.g., Marandi (1991) pp. 419-475.

4 Berg-Schlosser (2002) pp. 319-323.

5 Stephens and Kümmel (2002) p. 62.

6 Linz (1978) pp. 27, 70.

7 Capoccia (2005) pp. 8-9.

8 Marandi (1991) pp. 476-498; Kasekamp (1999) pp. 65-66, 154-159; Kasekamp (2018) pp. 77, 87; Valge (2009) pp. 53-56.

9 Mudde (2007) pp. 22-23, 30-31. 
the only small number of in-depth researches in only a few languages that they were able to use in their analysis. Even less research has been done on how the coup of 1934 affected Estonia's international position. Estonia is rarely mentioned in the general studies of the history of 1930 s international relations, and the details regarding other countries' relations with Estonia are only clarified in limited research dedicated to more specific topics.

The relations of the Soviet Union, Germany, Poland and Great Britain with Estonia between the two world wars have been studied by Magnus Ilmjärv. ${ }^{10}$ The author primarily analysed the correspondence between Moscow and the Soviet Embassy in Tallinn, and, according to the author, the leadership of the Soviet Union approved of the 1934 coup in Estonia. Jaak Valge has studied the attitudes of three foreign states - Great Britain, Germany and the Soviet Union - towards the Päts coup. According to Valge, the coup did not result in any particular condemnation by the governments of these states, probably because they did not have precise information about events in Estonia, their possibilities to influence Estonian domestic politics were limited, and they had not formed close ties with the Veterans. ${ }^{11}$ Heino Arumäe, in his book on relations between Estonia and Finland in the interwar period, claims that the Finnish leadership approved of the coup. ${ }^{12}$ Of the foreign researchers, it is Russian historians Oleg Ken and Aleksandr Rupasov who have studied the relations of the Soviet Union with Estonia most comprehensively. Although Päts may have been the Soviets' preferred candidate for head of state in the 1934 elections and they understood the purpose of his coup, the researchers have not found any evidence that the Soviet Union supported him. ${ }^{13}$ Seppo Zetterberg has also analysed the events of 1934 in Estonia from a Finnish perspective to a limited extent. ${ }^{14}$

Since previous authors have studied the coup that took place in Estonia in 1934 in varied detail, and from various viewpoints, the author of this article plans to analyse, in depth, what information the foreign diplomates did hold regarding the coup of 12 March, the events leading up to the coup, and its consequences. In addition, the article assesses how the establishment of an authoritarian regime affected the relations

\footnotetext{
${ }^{10}$ Ilmjärv (2004a) pp. 84-85, 102-104. In 2010, a second revised edition of the book was published in Estonian. The references are to the latter if there were viewpoints presented there that were missing in the 2004 English language publication.

${ }^{11}$ Valge (2011) pp. 807-808; Valge (2012) pp. 60-61.

12 Arumäe (2018) p. 347.

${ }^{13}$ Ken and Rupasov (2002) pp. 240-241; Ken and Rupasov (2014) pp. 436-437, 440-441, 446-447.

14 Zetterberg (2021).
} 
Estonia had with foreign states. Six states are therefore studied, which were all important for Estonia, although for differing reasons. Firstly, Great Britain - one of the major military supporters of Estonia during the War of Independence, and from the Estonian perspective, the most valued major international power. Then there were another two democratic states with whom Estonia strove to intensify contacts - Finland and Sweden. The fourth state was Estonia's southern neighbour Latvia, which also relinquished democratic governance as a result of a 1934 coup d'état. And finally, the two dictatorships that posed the greatest security threat to Estonia - the communist Soviet Union and national socialist Germany.

The main sources for this study are the reports to their homelands sent by diplomats from the six countries who were residing in Estonia. These were preserved in the archives of the respective countries, except for the documents from the German Auswärtiges Amt, which the author of this article studied in the National Archives of the United Kingdom, where they ended up as a result of the Second World War. Unfortunately, there are materials pertaining to the diplomatic activities in Estonia between the two world wars by the countries being studied that have not so far been entirely available to researchers, or have not survived intact.

The document collection covering the anti-Estonian espionage activities of the Joint State Political Directorate under the USSR Council of People's Commissars (OGPU), is preserved in the National Archives of Estonia, where the Estonian internal political situation in 1933 and 1934 is also described.${ }^{15}$ Based on these documents, the information held by the OGPU on the events in Estonia in 1934 was limited. Due to lack of access to the relevant Russian archives, it is not possible, however, to adequately assess the actual level of knowledge held by the Soviet intelligence services on events in Estonia.

It is also difficult, based on the reports by Estonian diplomats, to clarify the attitudes of the foreign states on the 1934 coup since the documents of the Estonian embassies have only been partially preserved. According to M. Ilmjärv, after the signing of the Molotov-Ribbentrop Pact, the Estonian embassies in Moscow, Riga and Helsinki were ordered to destroy documents that could discredit the Estonian state. ${ }^{16}$ The documents of the Estonian Embassy in Berlin have also only been partially preserved. There is, however, important information in the overviews of the more important internal and foreign political events that were regularly sent to Estonian ambassadors abroad by the foreign ministry, which the ambassadors apparently used as talking points in their contacts with the governments of the foreign states.

\footnotetext{
${ }^{15}$ National Archives of Estonia (hereinafter RA) ERAF 138SM-1-54.

${ }^{16}$ Ilmjärv (2004a) p. 35.
} 
This article consists of five sections. The first section attempts to identify those people who provided information to the foreign diplomats in Estonia. In the following sections, the important stages in the Estonian domestic political crisis in 1933 and 1934 are analysed, using the reports of foreign diplomats and the positions of the Estonian foreign ministry as sources. In the last section of the article, there is an attempt to analyse whether, and how, the 1934 coup affected the relations with Estonia of the six countries under observation.

\section{The sources of information for the foreign diplomats residing in Estonia}

In order to assess the reliability of the information that was sent by the diplomats of the six states to their homelands at the end of 1933 and in 1934, the following aims to identify the circle of people with whom the diplomats had contacts during this period in Estonia. It should be noted that all the states had embassies in Tallinn except Great Britain, who had only a consulate in Tallinn.

Although the British ambassador, Sir Hughe Knatchbull-Hugessen was resident in Riga, Latvia, he usually met on his trips to Estonia the head of government and other ministers, as well as members of the diplomatic corps. The resident consul A. J. Hill mentioned in his reports numerous discussions with Estonian foreign minister Julius Seljamaa, as well as contacts with journalists and influential businessmen.

In the reports by the USSR Tallinn embassy, and the diaries of the diplomats, there are mentions of meetings with government head Päts and foreign minister Seljamaa, with numerous well-known socialists and left-wing union representatives, businessmen, public and cultural figures. In summer 1933 the Soviet embassy and the leadership of the Estonian Socialist Workers' Party (ESTP) concluded an agreement to exchange information on the Veterans. ${ }^{17}$ In August 1933 the People's Commissariat for Foreign Affairs (NKID) began requiring the embassy to make contact with the Veterans, but the ambassador Aleksei Ustinov reported to Moscow at the beginning of March 1934 that this had been unsuccessful. ${ }^{18}$ The task of collecting information on the Veterans was also allocated to the OGPU, but those Soviet spies in Estonia that are currently known to us, could

${ }^{17}$ Ilmjärv (2010) pp. 157-158.

${ }^{18}$ Stomonyakov to Antipov 15.10.1933: The Archive of the Foreign Policy of the Russian Federation (hereinafter AVPRF) 0154-26-37-2, 51-54; Ustinov to Stomonjakov 08.03.1934: AVPRF 0154-27-38-3, 29-31. 
not have provided the Soviet leadership with important information on the events covered in this article. ${ }^{19}$

German ambassador Otto Reinebeck had contacts with Päts and other members of the government, also with representatives of the local BalticGerman minority. The German embassy also received information from anonymous sources. The German ambassador was the only one who in his reports mentioned contacts with "influential members of the Veterans' movement". ${ }^{20}$ But the ambassador does not name anyone, nor is it known whether he would have received information from them regarding the events associated with the 1934 coup. Estonian historians who have studied the Veterans' movement have not found any definitive proof of their contacts with, or financing by, any German state institutions, including the National Socialist German Workers' Party (NSDAP). ${ }^{21}$ It is also stated in the collection of German foreign policy documents that "Documents that would indicate contacts between this organisation [i.e., the Veterans] and German authorities have not been found."22

Finnish ambassador Paavo Hynninen had a good opportunity for contacts with Konstantin Päts since the government head lived in the building owned by the Finnish embassy. ${ }^{23}$ Hynninen frequently mentioned Päts as a source for the information sent to Helsinki. According to Arumäe, Finnish diplomats were also generally well informed on the Estonian situation, and Hynninen was "one of us" in Estonian governmental circles. ${ }^{24}$

The Latvian ambassador Roberts Liepiṇš also stood out as being very well informed, for his objective analysis of Estonian politics and the accurate forecasting of subsequent events. In the reports sent to Riga, the diplomatic corps in Tallinn and members of the Estonian government were listed as sources, as well as anonymous sources, including persons in contact with the Veterans.

The contacts for the Swedish ambassador are difficult to ascertain since Anders Kozkul did not generally identify them in his reports, which were

\footnotetext{
${ }^{19}$ Rosenthal and Tamming (2013) pp. 63, 492-494.

${ }^{20}$ Reinebeck to the foreign ministry 02.12.1933: The National Archives (United Kingdom) (hereinafter TNA) GFM 33/3274.

${ }^{21}$ Marandi (1991) pp. 476-498; Kasekamp (1999) pp. 155-156; Arumäe (2007) p. 31; Valge (2009) pp. 53-56.

${ }^{22}$ Commentary by the compilers of the document collection that was added to the report sent by Reinebeck to the Auswärtigen Amt on 1 August 1934 (Akten zur deutschen auswärtigen Politik (1973) p. 272).

${ }^{23}$ History of the building on the website of the Finnish embassy. https://finlandabroad.fi/ web/est/saatkonnahoone (accessed on 13 January 2020).

${ }^{24}$ Arumäe (2018) p. 332.
} 
studied for the writing of this article. It seems that Swedish diplomats obtained a lot of information from the media or from journalists.

Therefore, the reports by the diplomats from the six states were mostly based on the information gleaned from the leading politicians of the parliamentary parties, higher state officials, military personnel, journalists and businessmen. Very many of these were biased as regards the Veterans - competing politicians and civil servants in the power struggle and journalists over newspaper circulation and advertising income..$^{25}$ The diplomats from the states covered here never indicated that their information on the pivotal events of the end of 1933 and 1934 had come from the Veterans, which means that the governments of the foreign states assessed the events in Estonia on the basis on information gained only from the Veterans' political opponents. For example, it was difficult for diplomats to forecast the results of the referendum and elections that took place during this period, as no public opinion polls were conducted and they could only rely on estimates from their contacts.

\section{Late 1933: the referendum}

In October 1933 a referendum took place in Estonia on the constitutional amendments initiated by the Veterans. The 1920 constitution was very liberal and parliament-centred, and there was no provision for the institution of head of state. The economic and social problems caused by the worldwide economic crisis at the start of the 1930s resulted in a deep mistrust in Estonia towards the political elite, the parties and the parliament, and the Veterans who joined the political fray at the beginning of the decade began to promote amendments to the constitution as a solution to these problems. ${ }^{26}$ According to the draft constitutional amendment that was put to referendum, the number of parliamentary seats was reduced from hundred to fifty, and the institution of a powerful head of state to essentially rule the country was to be created. The Veterans' draft was also supported by the later 1934 coup organisers Konstantin Päts and General Johan Laidoner. The referendum that took place 14-16 October 1933 resulted in

${ }^{25}$ After the Veterans joined the political fray it became clear that many of the politicians in the parliamentary parties would have missed out on a parliamentary seat in the elections scheduled for April 1934. The popularity of the Veterans' newspapers was also on the rise. The Veterans' relations with other newspapers were damaged by the former's attempts to boycott the newspapers due to their articles criticising the Veterans (Arumäe (2007) pp. 28-53; Marandi (1991) pp. 331-332, 362-363; Kasekamp (1999) pp. 62, 86).

${ }^{26}$ The reasons for changing the 1920 constitution are covered, for example, by Pajur (2018) pp. 357-371. 
a very large majority of voters supporting the constitutional amendments (73\% of those who voted, $56 \%$ of eligible citizens). After the results of the referendum were declared, the government of Jaan Tõnisson resigned and a transitional government was formed by Päts, with the main task of ensuring the implementation of the constitutional changes. ${ }^{27}$

Before the referendum, the ambassadors of the countries studied here were concerned about the possible results of the referendum and a possible coup attempt by the Veterans if the referendum fails. Such fears were caused by a very tense campaign organised by both the supporters and opponents of the constitutional amendments and attempts by the authorities to take administrative measures to prevent the Veterans' draft from winning. ${ }^{28}$ However, researchers have not yet found any proof of a coup planned by the Veterans at the end of 1933. After the referendum, the British, German, Latvian and Finnish ambassadors stated in their reports that the domestic political tension in Estonia had decreased. The Veterans were accused of ties to the German National Socialists by their opponents, but the British and German ambassadors did not consider it possible for historical reasons, and the Latvian ambassador also described the Veterans as a national movement. ${ }^{29}$ The Soviets were the most pessimistic. According to the assessment of the USSR NKID, the "fascismization" of Estonia would take place in any case, but should the referendum fail, a coup attempt by the Veterans could not be excluded. The diaries of the diplomats in the Tallinn embassy show that the information discrediting the Veterans was mostly provided to the Soviets by Estonian socialists - the fiercest political opponents of the Veterans. ${ }^{30}$

During this period, Estonian ambassadors in London, Moscow and Stockholm tried to calm down the governments of the respective countries

27 See, e.g., Pajur (2005) pp. 86-90.

${ }^{28}$ Marandi (1991) pp. 230-239.

${ }^{29}$ Knatchbull-Hugessen to Simon 11.11.1933: TNA FO 371/17184; Reinebeck to the foreign ministry 24.10.1933, 02.12.1933, 07.12.1933: TNA GFM 33/3274, TNA GFM 33/3486; Liepiṇš to Salnais 17.10.1933: The Latvian State Historical Archives (hereinafter LVVA) 1303-1-10828, 517-525; Liepiṇš to Salnais 05.12.1933: LVVA 2575-8-35, 61-67; Hynninen to the foreign ministry 30.09.1933, 17.10.1933: The Archives of the Ministry for Foreign Affairs of Finland (hereinafter UM) 5 C 12, Viro; Swedish embassy in Tallinn to B.Ö. Unden 27.09.1933: The National Archives of Sweden (hereinafter SRA) 230032.1, F 1:4, HP 1 (Ee), 1933-1934. "Historical reasons" here refers to the national memory of the centuries-long and substantial role of the German elite in governing the Estonian territory that ended with the founding of the Republic of Estonia.

${ }^{30}$ Stomonyakov to Antipov 15.10.1933: AVPRF 0154-26-37-2, 51-54; Antipov's and Klyavin's diaries $09.08 .1933,15.08 .1933,20.09 .1933,04.10 .1933,12.10 .1933$, 22.10.1933, 26.10.1933, 28.10.1933: AVPRF 0154-26-37-5, 153-155, 170, 175-176, 200-201, 208, 219-222. 
and denied rumours about Estonia's domestic political instability and the threat posed by the Veterans. ${ }^{31}$ The Estonian foreign ministry also denied that the Veterans had coup intentions and referred to the lack of information about their ties with national socialists. ${ }^{32}$ The neutral position of the ministry at that time could be explained by the fact that the Veterans had not yet announced their intention to join the election campaign, and that their plan to amend the constitution was also supported by a part of the current political elite.

\section{Early 1934: the election campaign}

The amended constitution entered into force on 24 January 1934, and during the subsequent one hundred days, elections for a powerful head of state and a smaller parliament were to take place. The main attention was naturally concentrated on the elections for head of state, where four candidates had been nominated: by the Veterans - their official leader retired General Andres Larka, by the Farmers' Party - Konstantin Päts, the head of the transitional government, by the election committee that was based on the Settlers' Party - retired General Johan Laidoner, commander-in-chief of the armed forces during the War of Independence, and by the ESTP - their leader August Rei. Prior to the nomination of the candidates, there was a brief, fruitless testing of the waters between Päts and the Veterans, aimed at gaining Veterans' support for his candidature. ${ }^{33}$ More serious, but just as fruitless were the negotiations held with the Veterans by Laidoner. Not supporting Päts or Laidoner as a candidate has been called the Veterans' fatal mistake. ${ }^{34}$ The number of signatures required to support the head of state nomination does not indicate the actual popularity of the candidates, but Larka's overwhelming support ${ }^{35}$ could have alarmed Päts and Laidoner in that the Veterans' candidate could gain the absolute majority needed to win in the first round.

${ }^{31}$ Kallas to the foreign ministry 19.09.1933: RA ERA 957-13-743, 50-51; Tofer to the foreign ministry $06.09 .1933,25.10 .1933$, Kirotar to the foreign ministry 04.12 .1933 : RA ERA 957-13-532, 54-55, 94-95, 102-104; Akel to the foreign ministry 15.08.1933: RA ERA 957-13-749, 10.

32 Estonian foreign ministry's political overviews August-October 1933: RA ERA 975-13767, 31-32; RA ERA 957-13-769, 15, 19-19p, 36, 66-67.

33 Information about these negotiations reached even the ears of Soviet diplomats Antipov to Stomonyakov 29.01.1934: AVPRF 0154-27-38-3, 2-4.

${ }^{34}$ Marandi (1991) pp. 376-382; Kasekamp (1999) p. 55.

35 The requirement was 10,000 signatures, but by 11 March Larka had collected 52,436 , Laidoner 18,220, Päts 8,969 and Rei 2,786 (Valge (2019) p. 434). 
None of the diplomats of the six countries could predict the winner of the elections. The Latvian ambassador, in his 7 December 1933 report, expressed opinion that in the case of Larka's victory, the future would be unpredictable. If Laidoner wins, Estonia could strengthen relations with Poland. Liepinš nevertheless hoped that foreign policy would remain in the hands of professional diplomats and that major changes would not take place in this field. ${ }^{36}$ According to the assessments by the Finnish ambassador in January 1934, no candidate would achieve the necessary majority to win in the first round, and that in the second round General Larka would compete against either Päts or Laidoner. ${ }^{37}$ The Swedish ambassador, whose information was based on newspapers, predicted that most likely there would not be a clear winner in the first round of the elections, whereas in the second round Päts would have the best chance since he could also have the support of the Veterans, who opposed Laidoner. Kozkul also drew attention to the Veterans' aggressive election campaign which was not directed at promoting a clear political program, but at attacking the opponents. ${ }^{38}$

According to the diaries and reports of the USSR diplomats, contradictory opinions were sent to Moscow in the end of 1933 and beginning of 1934 on the winner of the elections. Apparently, it depended on which contacts the diplomats had happened to have. Among prominent Estonians the most likely winner of the elections was Päts, who was also considered as the most suitable candidate for the Soviets. ${ }^{39}$ At the same time the Soviet embassy did not have a clear understanding of how the coming to power of the Veterans could affect Estonian relations with Moscow. On March 8, Soviet diplomats reported to Moscow on rumours about a coup d'état planned by Päts. ${ }^{40}$

The British ambassador refrained from predicting the election results in his report of 1 March, because "it is unnecessary to weary you with a forecast of chances of the four presidential candidates." Although it had been claimed in previous numerous embassy reports that national socialist activities were not a serious threat in Estonia, the ambassador wrote

${ }^{36}$ Liepiṇš to Salnais 07.12.1933: LVVA 2575-8-35, 68-76.

${ }^{37}$ Hynninen to the foreign ministry 18.01.1934, 26.01.1934: UM 5 C 12, Viro.

${ }^{38}$ Kozkul to Sandler 01.03.1934: SRA 230032.1, F 1:4, HP 1 (Ee), 1933-1934.

${ }^{39}$ Diaries of Klyavin and Antipov 02-03.11.1933, 07.11.1933, 10.11.1933, 22.11.1933, 23.11.1933, 04.12.1933: AVPRF 0154-26-37-5, 188, 194, 198, 211, 225, 231, 234-235, 240-241, 257; Antipov to Stomonyakov 09.01.1934, 20.02.1934, 08.03.1934: AVPRF 0154-27-38-3, 10-11, 13-14, 29-31.

${ }^{40}$ Ustinov's diary 19.02.1934: AVPRF 0154-27-39-7, 5; Ustinov to Stomonyakov 07.03.1934, 08.03.1934: AVPRF 0154-27-38-3, 21-23, 29-31; Antipov to Stomonyakov 08.03.1934: AVPRF, 05-14-102-109, 24-25. 
to London on 1 March that a number of official sources had confirmed the covert financing of the Veterans' campaign by the national socialists. Päts promised the ambassador that he would end the Veterans' activities as soon as he had sufficient facts and power. ${ }^{41}$

\section{March: the coup d'état}

On 12 March 1934, the government led by Konstantin Päts declared a six-month state of emergency in Estonia, appointed General Laidoner commander-in-chief of the armed forces, shut down the Estonian War of Independence Veterans' League, and arrested several hundred leading Veterans. There was no resistance to the coup. ${ }^{42} \mathrm{~A}$ parliamentary session took place on 15 March, where Päts justified his actions with the planned seizure of power by the Veterans, the subsequent risk of civil war and external danger, and referred to the people's "serious illness", who had thereby lost the right to participate in deciding matters of state. On 16 March, the parliament approved the establishment of a state of emergency. ${ }^{43}$ On 19 March, Päts postponed, until the end of the state of emergency, the elections for the head of state and parliament that were to be held in April. The authorities began to restrict the freedoms of speech and assembly, the activities of all parties were halted, and media censorship was established. A subsequent investigation found no evidence of the Veterans having plotted a coup. ${ }^{44}$

On 7 September Päts extended the state of emergency by one year, which meant that the elections were once again postponed and that the authoritarian regime continued. An extraordinary parliamentary session took place from 28 September to 2 October, which Päts demanded be cut short since a number of parliamentarians began criticising government policies. In the subsequent years Päts governed without a parliament, using decree legislation that was foreseen for the head of state, in the case

${ }^{41}$ Knatchbull-Hugessen to Simon 13.01.1934: TNA FO 371/18230; 24.01.1934: TNA FO 419/28; 30.01.1934, 01.03.1934: TNA FO 371/18236.

${ }^{42}$ As of February 1934, the Veterans began receiving hints from their supporters who worked in state institutions regarding Päts's intentions, but the movement's leaders decided not to react. They believed that since they could not be accused of anything, any repression carried out by the authorities would be short term and would be good publicity for the Veterans. Päts, however, knew that the Veterans had decided not to resist (Marandi (1991) pp. 412-414; Kasekamp (1999) pp. 100-101).

${ }^{43}$ Riigikogu V koosseis (1934) pp. 1435-1438, 1459.

${ }^{44}$ During the court session that took place on 12-20 June 1935, thirty-seven Veterans were only found guilty of organizing a bitter political fight that endangered public security, and were given short suspended prison sentences: RA ERA 927-2-4, 432-435. 
of "urgent state necessity", in the constitutional amendments that were approved by the referendum in October 1933.

The British embassy informed London of the establishment of a state of emergency in Estonia on 13 March. The report notes that according to the media the Veterans planned a putsch. On 16 March the consul A. J. Hill described the speech that Päts had given on the previous day in the parliament as disappointing, since Päts made no sensational disclosures. The Estonian ambassador in London, Oskar Kallas, visited the Foreign Office's head of the Scandinavian and Baltic States department, Lawrence Collier, on 13 and 16 March, and in Kallas's assessment, Collier was satisfied with the actions of the Estonian government. ${ }^{45}$

During the following months, Estonian politicians and diplomats repeatedly assured British diplomats that the restoration of democracy was the ultimate goal of Päts's government, but that it would take more time to achieve this. The Britons concluded from this that the Estonian government wished to preserve the dictatorial powers that they held and would not risk elections since they were unsure of a favourable electoral result. In the 1934 annual report by the British embassy in Riga, the Estonian system of state is described as a "virtual dictatorship", and it was claimed that the reason for the coup d'état was Päts's fear of losing the elections to Larka. ${ }^{46}$

The immediate reaction by the USSR NKID and its Tallinn embassy to the coup is unknown due to the lack of archival documents. The Estonian ambassador in Moscow, Karl Tofer, referred in his 15 March report to an article published in Pravda, the organ of the All-Union Communist (Bolshevik) Party (VKP(b)), according to which the coming to power of the fascists, i.e., Veterans, could have presented a threat to Estonian independence. In Tofer's opinion this was an accurate description of the view held by "Moscow official circles". ${ }^{47}$

In the subsequent correspondence between the NKID and the Tallinn embassy, the defeat of the Veterans was deemed to be positive from the standpoint of Soviet and Estonian relations. At the same time, the ambassador A. Ustinov called the new regime in Estonia the "dictatorship of Päts and Laidoner" and stated that there was a generally accepted opinion that Päts would agree to holding presidential elections only if he was sure he could win. The extraordinary session of the parliament at the end of

\footnotetext{
${ }^{45}$ Knatchbull-Hugessen to Simon 13.03.1934, 22.03.1934: TNA FO 371/18236; Kallas to the foreign minister 17.03.1934: RA ERA 1583-2-3, 100.

${ }^{46}$ Knatchbull-Hugessen to Simon 23.03.1934, 31.08.1934: TNA FO 371/18236; Torr to Simon 30.01.1935: TNA FO 371/19400.

${ }^{47}$ Tofer to the foreign ministry 20.03.1934: RA ERA 957-13-532, 133-135.
} 
September, beginning of October, was described by Ustinov as a comedy played out to justify Päts's government's actions. ${ }^{48}$

According to the report sent by the German ambassador on 15 March to Berlin, the Veterans were not planning an armed uprising and the real reason for Päts's actions were the good prospects for the Veterans in the coming elections. On 20 March Reinebeck informed Berlin of Päts's decision to postpone the elections and doubted that democracy would soon be reinstated in Estonia. In his 23 April and subsequent reports, he called the Estonian government the "Diktaturregierung Päts-Laidoner". In the autumn, Päts spoke to the German ambassador of the need to amend the new constitution and claimed that the government's course would not change until the reform had been implemented. ${ }^{49}$

The Latvian ambassador, in his report sent to Riga on 13 March, also doubted the explanations of the Estonian authorities. In R. Liepiňšs's opinion, the Veterans would only have had reason for a coup if they had not succeeded in the elections. ${ }^{50}$ In his subsequent reports Liepiṇs repeatedly called the system of government in Estonia the "Päts-Laidoner dictatorship". He did not believe that Estonia would revert in the near future to a parliamentary system - it was more likely that yet another amendment of the constitution would take place. ${ }^{51}$

Estonian foreign minister J. Seljamaa left on 15 March on a visit to Finland, during the course of which he met with the Finnish president and other leading statesmen. In his research, H. Arumäe concluded, based on the memos written in both the Estonian and Finnish foreign ministries, that Finnish politicians in general approved of the actions by the Estonian government. ${ }^{52}$ However, the Finnish ambassador, P. Hynninen, reported to Helsinki after the coup that although Päts received praise from all the parliamentarians on 15 March, he made no sensational disclosures regarding the Veterans, and that there was apparently no basis for the stories that the Veterans were plotting a coup. In the following

\footnotetext{
${ }^{48}$ Stomonyakov to Ustinov 25.03.1934: AVRRF 0154- 27-26-2, 34; Ustinov to Stomonyakov 28.03.1934: AVPRF 0154-26-37-2, 20-22; 08.05.2020: AVPRF 0154-27-38-3, 64-65; Ustinov to Litvinov 17.10.1934: AVRRF 0154-27-38-3, 56.

${ }^{49}$ Reinebeck to the foreign ministry $15.03 .1934,20.03 .1934,23.04 .1934,18.05 .1934$, 12.09.1834: TNA GFM 33/3274.

${ }^{50}$ Liepiṇš to Munters 13.03.1934: LVVA 1303-1-10828, 595-603.

${ }^{51}$ Liepiṇš to Ulmanis 17.04.1934, 18.04.1934: LVVA 2575-8-36, 406-413p, 414-429p; 11.10.1934: LVVA 2575-8-37, 63-74p.

${ }^{52}$ Arumäe (2018) pp. 346-347.
} 
reports, the ambassador referred to dictatorial rule in Estonia and noted that the restoration of democracy may prove to be complicated..$^{53}$

In his reports sent to Stockholm, the Swedish ambassador described the explanations given in the Estonian media regarding the threats posed by the Veterans, for which, in his words, the Estonian government did not present any confirming evidence. All the parties supported Päts's actions, and the newspapers voiced their approval. A. Kozkul opined that the elections would be postponed indefinitely. ${ }^{54}$

The domestic and foreign policy overviews compiled by the Estonian foreign ministry for the Estonian diplomats abroad were in accordance, after 12 March, with the government's rhetoric and, based on what is currently known to researchers, were largely untrue. In the 20 March overview, the Veterans organisation was described as being similar to the German national socialists, Italian fascists and Soviet Bolsheviks. The Veterans had supposedly been ordered to infiltrate state institutions and to be prepared for armed response. The overviews did not directly mention coup intentions by the Veterans, but claimed that the government needed to intervene in order to avoid an outbreak of conflict in the future. In the overview of 5 October, the entire blame for halting the parliamentary extraordinary session lay with the opposition, whose criticism of the government was said to be unfounded. ${ }^{55}$

\section{Foreign countries' relations with Estonia after the coup d'état}

The 1934 coup d'état and the establishment of an authoritarian regime did not result in substantial changes in the attitudes of foreign states towards Estonia. This is evident both from the reports of contemporary diplomats and from the findings of later researchers. There were several reasons for this.

Firstly, the establishment of an authoritarian regime in interwar Europe was nothing out of the ordinary, and according to Carr, alliances between democratic states and states who had relinquished democracy were often formed not because of ideological proximity, but based on common interest. ${ }^{56}$ Relinquishing democracy could also be seen as the only solution to the social and political problems caused by the worldwide economic crisis at the beginning of the 1930s, especially in states which did not

\footnotetext{
${ }^{53}$ Hynninen to the foreign ministry 19.03.1934, 15.05.1934, 03.10.1934, 23.10 1934: UM 5 C 12, 1934.

${ }^{54}$ Kozkul to Sandler 14.03.1934, 17.03.1934: SRA 230032.1, F 1:4, HP 1 (Ee), 1933-1934.

${ }^{55}$ RA ERA 957-13-769, 96-99; RA ERA 1583-2-4, 302-305.

${ }^{56}$ Carr (1947) pp. 262-263.
} 
have a tradition of longstanding political stability. ${ }^{57}$ In addition, during that period in Europe, there was a varied understanding of democracy, and democracy with complete electoral and citizen rights was in any case a very new phenomenon. ${ }^{58}$ Relations between Estonia and other countries after the coup d'état should be examined from this perspective.

Secondly, Estonia's international position was supported by the fact that a significant section of the existing political elite, including Konstantin Päts and General Laidoner who were amongst the best recognised Estonian statesmen, maintained its power as a result of the coup, and that it claimed that the rise to power of a political movement with ties to the German National Socialists, and a desire for dictatorship, had been avoided. After the coup, the foreign policy decision-making became the monopoly of a small group of people. ${ }^{59}$

Thirdly, those states whose positions are being examined in this paper were not necessarily even interested in deeper political relations with Estonia, beyond the usual diplomatic communication. Or the Estonian system of government was not important enough for them that its change would have led to a reassessment of foreign policy towards Estonia. That does not mean, however, that these states did not have strategic interests regarding Estonia.

Before the coup, Soviet diplomats directly stated that they considered K. Päts to be the most suitable candidate for the post of the head of state amongst the existing candidates. ${ }^{60}$ But as $\mathrm{M}$. Ilmjärv notes, although the 12 March coup d'état was subsequently approved in Moscow, the Soviets became quickly disappointed with Päts's politics, especially because he was unable or unwilling to get rid of General Laidoner, who was very ambitious in directing Estonia's foreign relations, but was considered an anglophile and polonophile. ${ }^{61}$ During the period under observation in this article, the Central Committee Politburo of the VKP(b), the highest policy-making authority of the party, rarely discussed topics associated with Estonia, and the measures and allocated funds to directly influence Estonia were insufficient, even from Moscow's viewpoint. After the 1934 coup, the Politburo made no decisions due to the changed Estonian domestic political situation. ${ }^{62}$

\footnotetext{
${ }^{57}$ Marks (2003) p. 139.

${ }^{58}$ Buchanan (2002) pp. 44, 47.

${ }^{59}$ Ilmjärv (2004a) p. 544.

${ }^{60}$ Klyavin's diary 04.12.1933: AVPRF 0154-26-37-5, 257.

${ }^{61}$ Ilmjärv (2004a) p. 103.

${ }^{62}$ Ken and Rupasov (2014) pp. 424-426, 433-440, 446-447, 449-451, 470-474; Valge (2011) pp. 798-799.
} 
Like Soviet diplomats, the German ambassador O. Reinebeck also predicted immediately after the coup, on 20 March, that it would have a positive effect on Estonian-Soviet relations. But according to the 1935 report by Germany's Tallinn embassy, relations between Estonia and the Soviet Union had cooled somewhat. Great Britain's embassy also claimed in their 1935 report that relations between Estonia and the Soviet Union were friendly but limited. ${ }^{63}$

The main rival to the Soviet Union as regards influence over Estonia was Germany. After rising to power, Hitler's aim was to achieve free reign in the eastern part of the European continent in order to resolve the German Lebensraum problem, and to achieve this primarily through agreements with the major powers that were dominant in European politics. ${ }^{64}$ Compared to this, Estonia's internal developments were of secondary importance. Although there are claims in some studies published in Estonia that in summer 1935 foreign policy in Estonia began to develop with an orientation towards Germany, there are few justifications for this claim, with intelligence cooperation directed against the Soviet Union as an exception. ${ }^{65}$

The 1935 and 1936 reports by the German embassy in Tallinn note positive developments in Estonia-Germany relations, both in economic and political fields, and referred to the increase in German influence in the region after the naval agreement concluded with Great Britain on 18 June $1935 .{ }^{66}$ Nevertheless, there is no basis to conclude that Estonia's foreign policy was completely German-oriented. ${ }^{67}$ The annual reports show that the German embassy in Tallinn was aware of the loss of democracy and the repression of the opposition, including the Veterans, by the authorities, but that there were no consequences to relations between the two countries. Later, the embassy began to praise the effectiveness of the authoritarian regime in Estonia. The then German ambassador to Tallinn, Hans Frohwein wrote in April 1938: "The authoritarian regime, with no parliament, that was established by a coup in 1934, and which has lasted until today, has been of great service to the state." 68

${ }^{63}$ Reinebeck to the foreign ministry 20.03.1934: TNA GFM 33/3274 and 10.01.1936: TNA GFM 33/2547; Torr to Eden 10.02.1936: TNA FO 371/20311.

${ }^{64}$ Schmidt (2002) pp. 117-120, 155-158.

${ }^{65}$ Ilmjärv (2004a) pp. 190-194; Ilmjärv (2004b) pp. 63-65, 70-73.

${ }^{66}$ Reinebeck to the foreign ministry 10.01.1936, Frohwein to the foreign ministry 26.01.1937: TNA GFM 33/2547.

${ }^{67}$ British diplomats in Estonia, for example, did not reach such a conclusion, according to the embassy's 1935 report - Torr to Eden 10.02.1936: TNA FO 371/20311.

${ }^{68}$ Frohwein to the foreign ministry 29.04.1938: TNA GFM 33/673. 
The most obvious proof of the lack of interest by Great Britain towards Estonia is that relations with Estonia are hardly mentioned in the British general foreign policy studies, either before or after the 1934 coup. ${ }^{69} \mathrm{Sir}$ Hughe Knatchbull-Hugessen, who served as ambassador for the Baltic states in 1930-1934, was essentially silent in his memoirs regarding the political interests of Great Britain towards the Baltic states. ${ }^{70}$ As mentioned earlier, Knatchbull-Hugessen did not even bother to analyse for the Foreign Office different candidates' prospects in the run-up to the April 1934 elections. $^{71}$

In the 1934 and 1935 reports by the British embassy in Riga, it was only economic matters that were noted as an important topic in the relations between Great Britain and Estonia. ${ }^{72}$ The same was also noted regarding British-Estonian relations by Germany's Tallinn embassy in its 1935 and 1936 reports. ${ }^{73}$ In their reports on Estonian politics in 1935-1937, British diplomats often assessed Estonia's domestic political developments from the perspective of how this would affect the popularity of the Veterans, whom they also called fascists and Nazi supporters. ${ }^{74}$ Like the Germans, the Britons also found positive sides to Päts's rule. The War Office's "historical sketch" written around October 1938, said that in Estonia "the period of authoritarian government was marked on the whole by an improvement in the internal condition." 75 The lack of interest by Great Britain regarding political topics associated with Estonia, and the focus on economic relations, is also emphasised in thematic research. ${ }^{76}$

According to the works covering Latvian general history that have been published after the restoration of independence, Latvia pursued the intensification of cooperation between the Baltic states in the first half of the 1920s, but the only result of this was a cooperation agreement with Estonia in 1923. The changes that occurred in the first half of the 1930s in the politics of European states, especially Hitler's coming

${ }^{69}$ See, e.g., Lee (1996); Pearce and Stewart (1996).

${ }^{70}$ Knatchbull-Hugessen (1949) pp. 60-71.

${ }^{71}$ Knatchbull-Hugessen to Simon 01.03.1934: TNA FO 371/18236.

${ }^{72}$ Torr to Simon 30.01.1935: TNA FO 371/19400; Torr to Eden 10.02.1936: TNA FO 371/20311.

${ }^{73}$ Reinebeck to the foreign ministry 10.01 .1936 , Frohwein to the foreign ministry 26.01.1937: TNA, GFM 33/2547.

${ }^{74}$ In the summer of 1935, a new British consul, W. H. Gallienne, arrived in Estonia, who had not witnessed the coup of 1934 by himself. His analysis of the domestic political situation in Estonia was usually quite understanding of Päts's politics (Kenkmann (2013) pp. 79-82).

${ }^{75}$ Frohwein to the foreign ministry 29.04.1938: TNA GFM 33/673; TNA WO 106/5143.

${ }^{76}$ E.g., Hinkkanen-Lievonen (1986) pp. 37-39, 43; Salmon (1988) pp. 114-115; Powell (2003) p. 194. 
to power in Germany, reinvigorated the need for cooperation between the Baltic states. ${ }^{77}$ In the agreement signed on 17 February 1934 in Riga, Latvia intensified its relations with Estonia, and on 12 September 1934 the so-called Baltic Entente agreement was signed in Geneva, on foreign policy cooperation between Estonia, Latvia and Lithuania. ${ }^{78}$ The authors of the works referred to in this paragraph do not note any differences between the foreign policies of democratic and authoritarian Latvia (and Estonia).

In spring 1934, Päts was considered by the Latvian embassy in Tallinn as the most suitable candidate for the post of head of state. ${ }^{79}$ Although Latvia was Estonia's most important interwar foreign policy partner, the relations between the states did not develop as far as was hoped. In the 1935 report by the British embassy in Riga, it is noted that the cooperation between Estonia and Latvia leaves something to be desired, and in the 1938 report it is said that the cooperation between the Baltic states weakens year by year. ${ }^{80}$

Finland, on one hand, had already committed in the 1920s to cooperation primarily with the Scandinavian states in order to ensure its security, which resulted in avoiding closer ties with Estonia and the other Baltic states. ${ }^{81}$ On the other hand, both before and after the 1934 coup, annual unofficial meetings were taking place between the Estonian and Finnish heads of state, and the Finnish president Pehr Evind Svinhufvud also visited Estonia in August 1934. Nevertheless, certain tensions in Estonian-Finnish relations arose after 1934. The Estonian leadership was dissatisfied with criticism of Finnish newspapers about the Estonian authoritarian regime and Finnish politicians were unsuccessfully waiting for the restoration of democracy in Estonia. ${ }^{82}$ Military and intelligence cooperation between Finland and Estonia against the Soviet Union also took place secretly throughout the interwar period. This cooperation was not affected by the coup d'état of 12 March and the subsequent changes in the leadership of the Estonian army. ${ }^{83}$

The 1936 report by the German embassy in Tallinn notes that although the Estonian-Finnish relations were good, the hope held by the Estonian

${ }^{77}$ Duhanovs, Feldmanis and Stranga (1994) pp. 8-12, 24-26; Bleiere et al. (2014) pp. 178-85.

${ }^{78}$ Arumäe (2018) pp. 376-382.

${ }^{79}$ Liepiṇš to Munters 17.04.1934: LVVA 2575-8-36, 414-429p.

${ }^{80}$ Torr to Eden 10.02.1936: TNA FO 371/20311; Torr to Eden 07.01.1939: TNA FO $371 / 23605$.

${ }^{81}$ Turtola (1988) p. 108; Arumäe (2018) pp. 383-384.

${ }^{82}$ Zetterberg (2021) pp. 128-133, 135-137, 150-153.

${ }^{83}$ Leskinen (2000) pp. 198-202. 
government for closer political cooperation was not fulfilled since Finland primarily wanted closer ties with the Scandinavian states. The same was said in the report on Estonia's relations with Sweden. ${ }^{84}$

The Finnish attitude to Estonia was strongly dependent on Swedish foreign policy. The motive of the latter in limiting contacts with the Baltic states was a fear regarding the proximity of the Soviet Union - since Sweden considered their independence to be insecure and temporary, it avoided concluding closer political ties with the Baltic states or taking political responsibilities. Sweden even considered Finland's active contribution to cooperation with Estonia and the other Baltic states as dangerous. At the beginning of the 1930s, the Baltic states and Sweden retreated even further politically from each other since social democrats dominated in Swedish politics, but in all the Baltic states there were authoritarian regimes in power. But the coup in Estonia was not the reason for the lack of close political relations with Sweden. ${ }^{85}$

\section{Conclusion}

In this study, there is an analysis of the assessments provided by diplomats from Great Britain, Sweden, Finland, Latvia, Germany and the Soviet Union of the coup d'état that took place on 12 March 1934 in Estonia. The initiator of the events being studied was the Veterans movement which became a political pressure group at the beginning of the 1930s. After the referendum that took place in October 1933, where the draft constitutional amendments that had been produced by them were overwhelmingly approved, the Veterans decided to also present their own candidates for the elections for head of state and parliament that were to take place in April 1934. The increase in popularity of the Veterans, and their rhetoric against the current political establishment, endangered the parliamentary parties, and the positions held by the officials, military and media who were associated with the parties. In the course of the coup, the Estonian War of Independence Veterans' League was banned and the elections postponed.

The reports by the foreign diplomats residing in Estonia, written with different frequency and a varying degree of detail, show that they had contacts mainly with the leading politicians of the parliamentary parties, state officials, senior officers, businessmen and journalists, of whom many were critical of the Veterans. The information on them sent

\footnotetext{
${ }^{84}$ Frohwein to the foreign ministry 26.01.1937: TNA GFM 33/2547.

${ }^{85}$ See, e.g., Carlgren (1995) pp. 14-19, 24-26; Jaanson (2001) pp. 273-274; Kuldkepp (2016) pp. 415-416; Trencsényi et al. (2018) p. 51 on this subject.
} 
by the diplomats to their capitals, therefore, was biased and conflicting, which increased the lack of awareness regarding the Veterans' ideology and political goals.

Prior to the referendum, in the autumn of 1933, and influenced by a tense election campaign, the foreign diplomats were concerned about the internal security of Estonia and negative in their description of the Veterans. After the clear win in the referendum, however, a reduction in tensions in society was noted. Although at the end of 1933 there was much speculation about the Veterans' contacts with Germany and the NSDAP, the foreign diplomats remarked in their reports as to the lack of respective proof, and also referred to the Estonians' historic anti-German attitudes, which would have made it difficult for the Veterans to explain such cooperation to the Estonian public.

The relatively neutral attitude towards the Veterans at the end of 1933 and the beginning of 1934 of Estonian politicians and public figures who were sharing information with foreign diplomats, can be explained by the lack of clarity regarding the political ambitions of the Veterans. At the same time negotiations were being held, and were failing, with Päts and General Laidoner on whether the Veterans would support one or the other in the coming elections. As the election campaign gathered steam the Estonian politicians and officials began to hint at the government's intention to get rid of the Veterans, and the foreign ministry's political overviews for Estonian ambassadors abroad in 1934 and especially after the 12 March coup became more critical of the Veterans. Diplomats from differing foreign states considered Päts to be the most suitable candidate for their homelands for the position of head of state with extensive powers, more than the head of the Veterans, General Larka.

As regards the coup carried out by the government on 12 March 1934, it is clear that diplomats from Great Britain, Germany, Finland, Latvia and Sweden doubted Päts's explanation of the need to avoid a coup by the Veterans. After the postponement of elections, the conviction deepened that Päts would continue the undemocratic rule indefinitely, and would not risk organising elections until he was sure of an election result that was beneficial to him. Although diplomats from both democratic and undemocratic countries residing in Estonia were forthright in their post-coup reports in calling the new Estonian system of government a dictatorship, their reports contained, besides a few ironic comments, no clear condemnation of the dismantling of democracy. After all, the authoritarian regime was in its repressions, relatively mild, the Estonian foreign policy course remained unchanged, and the court process in summer 1935 freed the Veterans of the coup-plotting charge, and did not result in severe penalties for the accused. 
The analysis of the relations between the six states and Estonia after 12 March is complicated, as previous researchers have mostly not raised the question of how it was affected by the 1934 coup and the establishment of an authoritarian regime. Based on the studies published so far, and the available documents in the archives of several countries, it can be concluded that the coup and the change of political regime did not damage Estonia's international position. On the contrary, the foreign ministries of a number of countries were understanding of Päts's actions, or even approved of them. Two dictatorships, the Soviet Union and Germany, were interested in increasing their influence in Estonia and the preservation of a democratic system of government was in comparison unimportant. Estonia's relations with the Soviet Union were not improved by Päts' remaining in power, and relations with Germany were not damaged because of the liquidation of the Veterans' movement, which had previously been accused of ties to the German National Socialists. Great Britain had decided to focus mainly on economic cooperation with Estonia. Considering the independence of the Baltic states to be uncertain, due to the proximity of the Soviet Union, the decision to avoid deeper political cooperation was made by Sweden, and following the latter's example, also Finland who had chosen a Scandinavian orientation. Estonia's relations with neighbouring Latvia were also not particularly close.

Lack of interest in closer political cooperation with Estonia could have resulted in the information that reached most of these states' capitals on Estonia, and especially on the Veterans, as being patchy, and also frequently contradictory since it was not considered necessary to collect more diverse information. In the following years, when the diplomats who witnessed the events had left Estonia, there already appeared in some British and German official documents praise regarding the efficiency of the authoritarian regime in Estonia compared to a democratic system of government.

In 1934 the replacement of a democratic government in Estonia with an authoritarian regime succeeded because of the combination of different factors. Firstly, the coup was supported by the clear majority of Estonia's existing political elite and media, whose views also dominated in the foreign diplomats' reports, and there being no resistance and no victims. And secondly, the interests of neighbouring countries and potential allies were elsewhere, and the foreign policy status quo offered by the coup organisers was seen as suitable by those major powers who were interested in influencing Estonia's future development. However, it is not known how the states being studied would have reacted to the coming to power of the Veterans after the 1934 April elections, since their foreign policy was initially hard to predict, and ties with Germany were unclear. 


\section{REFERENCES}

Akten zur deutschen auswärtigen Politik, 1918-1945: aus dem Archiv des Auswärtigen Amts, Serie C, 1933-1937. Band III, 1, Das dritte Reich: die ersten Jahre. 14. Juni bis 31. Oktober 1934. (1973), Göttingen, Vandenhoeck \& Ruprecht.

Arumäe, H. (2007), 1934. aasta 12. märts kaasaegsete hinnanguis. In: Velliste, A. (Ed.), Alasi ja haamri vahel. Tallinn, Konstantin Pätsi Muuseum, pp. 19-62.

Arumäe, H. (2018), Eesti ja Soome: sõjast sõjani. Tallinn, Argo.

Berg-Schlosser, D. (2002), Implications for Theories of Democracy. In: BergSchlosser, D. and Mitchell, J. (Eds.), Authoritarianism and democracy in Europe, 191939: comparative analyses. Basingstoke, Palgrave-Macmillan, pp. 319-323.

Bleiere, D., Butulis, I., Feldmanis, I., Stranga, A. and Zunda, A. (2014), History of Latvia: 100 years. Riga, Domas sēpks.

Buchanan, T. (2002), Anti-fascism and Democracy in the 1930s. European History Quarterly 32 (1), pp. 39-57. https://doi.org/10.1177/0269142002032001561

Capoccia, G. (2005), Defending Democracy: Reactions to Extremism in Interwar Europe. Baltimore and London, The Johns Hopkins University Press.

Carlgren, W. M. (1995), Rootsi ja Baltikum. Maailmasõdade vahelisest ajast sõjajärgsete aastateni. Ülevaade. Tallinn, Olion.

Carr, E. H. (1947), International Relations Between the Two World Wars. Houndmills, Macmillan.

Duhanovs, M., Feldmanis, I. and Stranga, A. (1994), Latvia and the year offateful decisions. Riga, University of Latvia.

Hinkkanen-Lievonen, M.-L. (1986), Britain as Germany's Commercial Rival in the Baltic States, 1919-1939. In: Recker M.-L. (Ed.), From competition to rivalry: the AngloGerman relationship in the countries at the European periphery, 1919-1939. Stuttgart, Steiner, pp. 15-49.

Ilmjärv, M. (2004a), Silent submission: formation of foreign policy of Estonia, Latvia and Lithuania: period from mid-1920s to annexation in 1940. Stockholm, Stockholms universitet.

Ilmjärv, M. (2004b), Eesti välispoliitika 1930. aastatel. In: Tannberg, T. (Ed.), Sõja ja rahu vahel. Koguteos. 1. köide: Eesti julgeolekupoliitika 1940. aastani. Tallinn, S-Keskus, pp. $51-73$.

Ilmjärv, M. (2010), Hääletu alistumine: Eesti, Läti ja Leedu välispoliitilise orientatsiooni kujunemine ja iseseisvuse kaotus 1920. aastate keskpaigast anneksioonini. $2^{\text {nd }}$ ed. Tallinn, Argo.

Jaanson, K. (2001), The Baltic Sea region in international relations of the twentieth century: The seminal nature of the interwar period. Journal of Baltic Studies 32 (3), 267-288. https://doi.org/10.1080/01629770100000091

Kasekamp, A. (1999), The Radical Right in Interwar Estonia. London, Macmillan Press.

Kasekamp, A. (2018), The Rise of the Radical Right, the Demise of Democracy, and the Advent of Authoritarianism in Interwar Estonia. In: Fleishman, L. and Weiner, A. (Eds.), War, Revolution, and Governance: The Baltic Countries in the Twentieth Century. Boston, Academic Studies Press, pp. 76-100. 
Ken, O. and Rupasov, A. (2002), Moskva i strany Baltii: opyt vzaimootnoshenii, 1917-1939 gg. In: Furman, D. E. and Zadorozhnyuk, E. G. (Eds.), Strany Baltii $i$ Rossija: obshestva i gosudarstva. Moscow, Referendum, pp. 225-256.

Ken, O. and Rupasov, A. (2014), Zapadnoye prigranichye: Politbyuro TsK VKP(b) i otnosheniya SSSR s zapadnymi sosednimi gosudarstvami, 1928-1934. Moscow, Algoritm.

Kenkmann, P. (2013), 1937. aasta põhiseadus - autoritaarse režiimi "reformimise" katse. Tuna (1), 70-89.

Knatchbull-Hugessen, H. (1949), Diplomat in Peace and War. London, John Murray.

Kuldkepp, M. (2016), Swedish political attitudes towards Baltic independence in the short twentieth century. Ajalooline Ajakiri (3/4), 397-430. http://dx.doi. org/10.12697/AA.2016.3-4.04

Lee, S. J. (1996), Aspects of British Political History 1914-1995. London, Routledge.

Leskinen, J. (2000), Vendade riigisaladus: Soome ja Eesti salajane sõjaline koostöö Nõukogude Liidu võimaliku rünnaku vastu aastatel 1918-1940. Tallinn, Sinisukk.

Linz, J. J. (1978), The breakdown of democratic regimes. Vol. 1, Crisis, breakdown, and requilibration. Baltimore and London, Johns Hopkins University Press.

Marandi, R. (1991), Must-valge lipu all, Vabadussõjalaste liikumine Eestis 1929-1937, I. Legaalne periood (1929-1934). Stockholm, Centre for Baltic Studies at the University of Stockholm.

Marks, S. (2003), The Illusion of Peace, International Relations in Europe, 1918-1933. Houndmills, Palgrave Macmillan.

Mudde, C. (2007), Populist radical right parties in Europe. Cambridge, Cambridge University Press.

Pajur, A. (2005), Suur kriis. In: Vahtre, S. (Ed.), Eesti ajalugu. VI, Vabadussõjast taasiseseisvumiseni. Tartu, Ilmamaa, pp. 81-91.

Pajur, A. (2018), Konstantin Päts. Poliitiline biograafia. II osa: riigimees (1917-1956). Tartu, Rahvusarhiiv.

Pearce, M. and Stewart, G. (1996), British Political History 1867-1995. Democracy and Decline. London, Routledge.

Powell M. J. (2003), The Battleground of High Politics: A Comparative Study of British and French Policies towards Poland and the Baltic States, 1917-1939. Lewes, Book Guild.

Riigikogu V koosseis. Stenograafilised aruanded. III ja IV istungjärk. (1934), Tallinn, Täht.

Rosenthal, R. and Tamming, M. (2013), Sõda enne sõda: Nõukogude eriteenistuste tegevusest Eestis kuni 1940. aastani. Tallinn, SE \& JS.

Salmon, P. (1988), British Security Interests in Scandinavia and the Baltic, 1918-39. In: Hinden, J. and Loit, A. (Eds.), The Baltic in international relations between the two world wars: symposium organized by the Centre for Baltic Studies, November 11-13, 1986, University of Stockholm, Frescati. Stockholm, Centre for Baltic Studies, pp. 113-136.

Stephens, J. D. and Kümmel, G. (2002), Class Structure and Democratization. In: Berg-Schlosser, D. and Mitchell, P. (Eds.), Authoritarianism and democracy in Europe, 1919-39: comparative analyses. Basingstoke, Palgrave-Macmillan, pp. 39-63.

Trencsényi, B., Kopeček, M., Lisjak Gabrijelčič, L., Falina, M. and Baar, M. (2018), A history of modern political thought in East Central Europe. Volume II, Negotiating 
modernity in the 'short twentieth century' and beyond. Part I, 1918-1968. Oxford, Oxford University Press.

Turtola, M. (1988), Aspects of the Finnish-Estonian Military Relations in the 1920s and 1930s. In: Hinden, J. and Loit, A. (Eds.), The Baltic in international relations between the two world wars: symposium organized by the Centre for Baltic Studies, November 11-13, 1986, University of Stockholm, Frescati. Stockholm, Centre for Baltic Studies, pp. 101-110.

Valge, J. (2009), Eesti vabadussõjalased ja Saksa natsionaalsotsialistid: ideoloogia, poliitiline taktika ja kontaktid. Tuna (3), 50-62.

Valge, J. (2011), Foreign Involvement and Loss of Democracy, Estonia 1934. Journal of Contemporary History 46 (4), 788-808. https://doi.org/10.1177/0022009411413408.

Valge, J. (2012), London, Berliin ja Moskva ning Eesti 1934. aasta riigipööre. Tuna (1), 38-61.

Valge, J. (2019), Eesti parlament 1917-1940: poliitiline ajalugu. Tallinn, Eesti Rahvusraamatukogu.

Zetterberg, S. (2021), Konstantin Päts ja Soome: unistus kaksikriigist. Tallinn, Varrak. 